\title{
Journal of Applied Phycology \\ Seasonal variation in the nutrient profile of Arthrospira fusiformis biomass harvested from an Ethiopian soda lake, Lake Chitu \\ --Manuscript Draft--
}

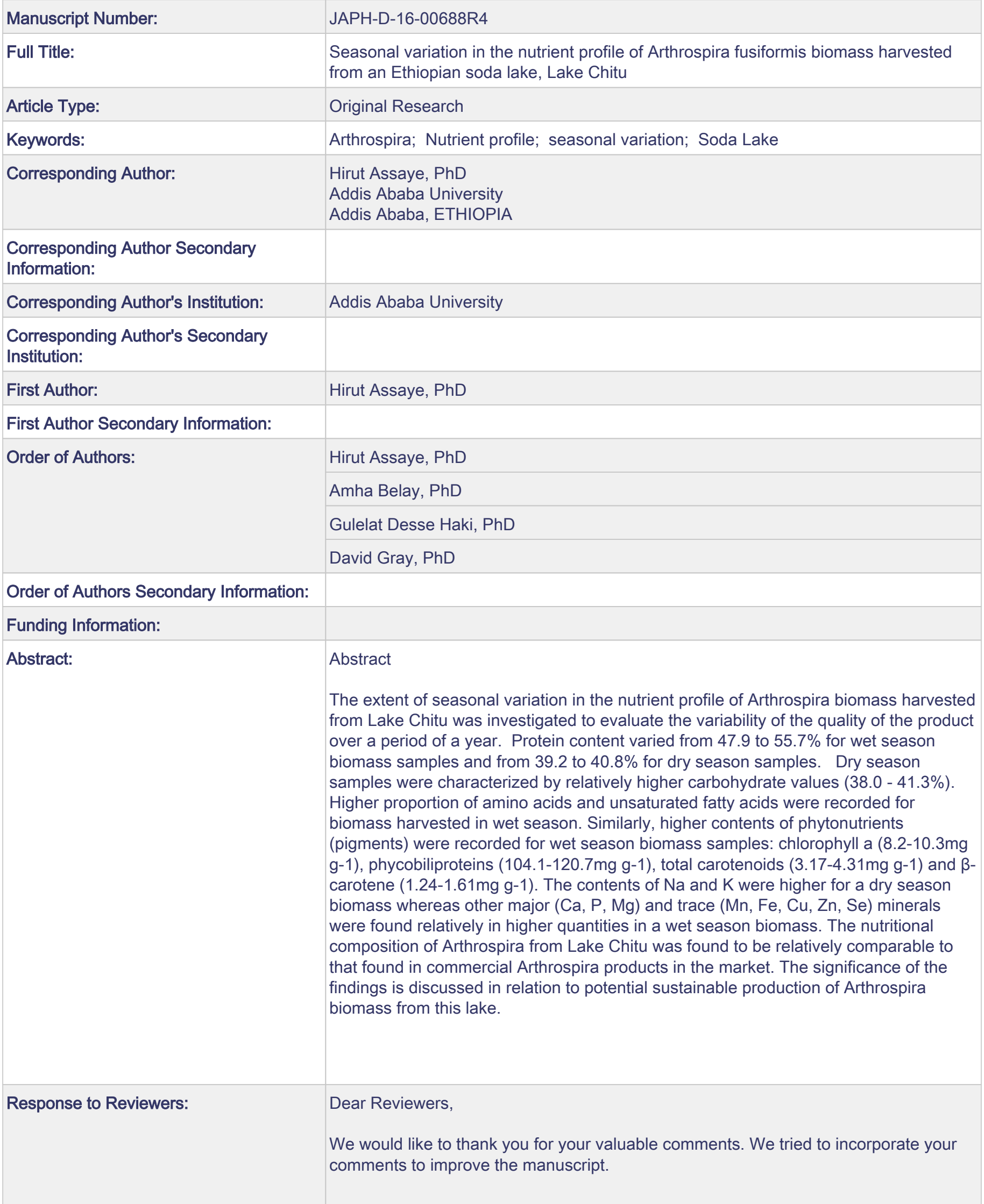


Sincerely,

Powered by Editorial Manager ${ }^{\circledR}$ and ProduXion Manager ${ }^{\circledR}$ from Aries Systems Corporation 


\section{Click here to view linked References}

Seasonal variation in the nutrient profile of Arthrospira fusiformis biomass harvested from an Ethiopian soda lake, Lake Chitu

Hirut Assaye ${ }^{\mathrm{a}}$, Amha Belay ${ }^{\mathrm{b}}$, Gulelat Desse ${ }^{\mathrm{a}}$, David Gray ${ }^{\mathrm{c}}$

a College of Natural Sciences, Center for Food Science and Nutrition, Addis Ababa University, Ethiopia

${ }^{\mathrm{b}}$ Earthrise Nutritionals, Irvine, CA, USA

c University of Nottingham, School of Biosciences, UK

Corresponding author: Hirut Assaye

e-mail: hirutas2000@yahoo.com

Tel: +251920469673 
Introduction

Arthrospira is known for its excellent nutritional composition as it contains high protein, essential fatty acids, minerals (especially iron), vitamins (especially beta-carotene and vitamin B12) and various bioactive phytonutrients with potential therapeutic effects (Belay 2002). For instance, its blue pigment, C-phycocyanin is reported to have antioxidant (Riss et al. 2007; Guan et al. 2009), anti-inflammatory (Shih et al. 2009), hepatoprotective (Aissaoui et al. 2017), neuroprotective (Bermejo-Bescós et al. 2008) and anti-cancer (Subhashini et al. 2004) effects. Besides, this pigment has high economic potential by being used-as a natural pigment for food, feed, drug and cosmetics (Cohen 1997). Carotenoids are also found in this cyanobacterium in large quantities-(Mendiola et al. 2005). Carotenoids are strong antioxidants as they are capable of scavenging potentially harmful radicals, which are commonly associated with the induction of some types of cancers (Stahl and Sies 2005). Secondary metabolites from Arthrospira have also gotalso have some biotechnological applications. For instance, a novel sulfatedpolysaccharide isolated from Arthrospira, Calcium Spirulan (Ca-SP), was found to be an inhibitor in the replication of several enveloped viruses including HIV-1 virus in vitro (Hayashi et al. 1996). This isolate has also showed shown an-inhibitory activity against metastasis and tumor invasion (Mishima et al.1998). Similarly, Okuyama et al. (2017) reported the ability of Arthrospira lipopolysacharides in inhibitingto inhibit tumor growth. Consequently, Arthrospira is produced in many countries either from natural lakes or artificial pond cultures to be used as a health food or as a protein supplement (Vonshak and Richmond 1988; Belay 2013). From data obtained from websites of various companies, Belay (2013) estimated an annual production of 10,000 tens of Arthrospira worldwide.

Arthrospira grows abundantly almost as a unialgal population in an Ethiopian soda lake, Lake Chitu, throughout the year (Wood and Talling 1988; Kebede 1997). Research done so far on Lake Chitu's Arthrospira mainly focused on its limnological aspects such as its growth behavior and light utilization efficiency (Kebede and Alghrein 1996), its tolerance limits to salinity and ionic concentrations (Kebede 1997), its-biomass concentration (Wood and Talling 1988), its-morphological variability in relation to environmental conditions (Ogato and Kifle 2014) and absence of cyanobacterial toxins (Willen et al. 2011). However, published data on the food value of Lake Chitu's Arthrospira biomass are lacking. The objective of this study was to examine the nutrient profile of Arthrospira biomass harvested from Lake Chitu in order to assess its suitability for use as food.

Materials and Methods

Description of Lake Chitu

Lake Chitu $\left(7^{\circ} 23^{\prime} \mathrm{N} 38^{\circ} 24\right.$ 'E) is a crater lake which lies at an altitude of 1600 m above sea level (Kebede et al. 1994) and located in the vicinity of Lake Shala about $287 \mathrm{~km}$ south of Addis Ababa, Ethiopia ( Fig 1). The lake is within a closed basin and lacks obvious surface outlet and inflows. It receives water from hot springs located at its shores as well as from direct precipitation (Kebede 1997). 
Sampling and sample preparation

Samples of Arthrospira biomass were collected every two months from March 2012 to January 2013. The biomass was harvested manually in plastic jars during morning hours when wind normally brings the biomass to the shallow area of the lake. Samples were taken randomly at the different sites of the lake and pooled. About 40 liters $-\underline{L}$ of biomass samples were taken at a time. During harvesting, the algal biomass was allowed to pass through a 0.425 $\mathrm{mm}$ sieve to remove insects, birds' hairfeathers and other extraneous materials. The harvested biomass samples were immediately transported to laboratory, filtered under vacuum by using a nylon cloth with-25_ $\mu \mathrm{m}$ nylon clothepenings and washed with distilled water to remove salts. The washed biomass samples were freeze dried using a freeze drier. The dried biomass samples were then grounded to powder and stored in brown bottles at $-20{ }^{\circ} \mathrm{C}$ until analysis.

Rainfall and temperature data

Rainfall and temperature data of the study area during the sampling period (March 2012-January 2013) were obtained from Ethiopian Meteorological Agency. Data recorded for the nearest meteorological station to the lake, Arsi Negele station, was used for the study. A "rainfall coefficient" for each month was calculated as the ratio between the monthly rainfall and one twelfth of the annual rainfall. A month is designated "wet"( rainy) when the monthly rainfall coefficient is greater than or equal to 0.6 (60\% of the rainfall module) (Zinabu 2002).

Physical and chemical parameters

The $\mathrm{pH}$ of the lake was measured with a pH-meter (Oakton pH 110, Eutech Instruments-Pty. Ltd., Singapore) and salinity was measured with a standard refractometer (0-100\%, Atago-Co. Lte). Carbonate-bicarbonate alkalinity was determined according to Golterman et al. (1978) by titration of the water with $1 \mathrm{~N}$ HCI to a pH of 4.5.

Water samples were also collected during wet and dry months to determine some inorganic minerals of the lake. Minerals were determined according to the standard analytical methods described in APHA/AWWA/WEF(1999): $\mathrm{Na}^{+}$and $\mathrm{K}^{+}$by flame photometric method, $\mathrm{Ca}^{2+}$ by direct nitrous oxide-acetylene flame method, $\mathrm{Mg}^{2+}, \mathrm{Fe}, \mathrm{Zn}, \mathrm{Mn}$, and $\mathrm{Cu}$ by direct air-acetylene flame method.

Biomass nutrient profile analysis

Proximate composition

Freeze dried Arthrospira samples were analyzed for their proximate composition using AOAC procedures. Moisture content was determined by drying a representative $\left(5 \_\mathrm{g}\right)$ sample for 4 hrs at $105^{\circ} \mathrm{C}$ (AOAC 2000; 925.09). Crude protein content $\left(\mathrm{N}_{\mathrm{x}} 6.25\right)$ was determined by employing the Kjeldahl method (AOAC 2000; 979.09) from-on a 0.5g 
Arthrospira powdersample. Lipids were quantified gravimetrically by exhaustively extracting 2_g sample in diethyl ether (boiling point, $55^{\circ} \mathrm{C}$ ) in a Soxhlet apparatus (AOAC 2000; 4.5.01). Ash was determined by incineration of 2.5 g sample in a muffle furnace at $550^{\circ} \mathrm{C}$ until a gray ash was obtained (AOAC 2000; 923.03). Crude fiber was determined after digesting 1.5 g of sample by refluxing with $1.25 \%$ boiling sulfuric acid and $28 \%$ of boiling potassium hydroxide (AOAC 2000; 962.09). Carbohydrate content was determined as the weight difference using protein, lipid, fiber, moisture and ash content data (James 1996).

Determination of amino acids

Amino acid analysis was performed according to AOAC (2005; 994.12). Briefly, samples were oxidized with a hydrogen peroxide/formic acid/ phenol mixture. Excess oxidation reagent was decomposed with sodium metabisulfite. The oxidized samples were hydrolyzed with $6 \mathrm{M}$ hydrochloric acid for 24 hrs. The hydrolysate was adjusted to $\mathrm{pH} 2.2$, centrifuged, and filtered. Amino acids were separated by ion exchange chromatography (Biochrom 20+ Amino Acid Analyser, Biochrom Ltd, Cambridge, UK) and determined after reacting with ninhydrin by using photometric detection at $570 \mathrm{~nm}$. The amino acids were identified and quantified by comparing peak profiles of the proteins with amino acid profiles from external amino acid standards.

Determination of fatty acids

For fatty acids determination, lipids were extracted from 0.1 g of biomass samples with chloroform-methanol-water (2:1:0.8) according to Bligh and Dyer method (Bligh and Dyer 1959). The extracted lipid was dissolved in $2 \mathrm{ml}$ chloroform. $1 \mathrm{ml}-\underline{\mathrm{mL}}$ of the mixture was transferred to a new glass bottle and $100 \_\mu 1-\mu \mathrm{L}$ of internal standard (mixture of methyl pentadecanoate glyceryl triheptadecanoate) was added it. Fatty acids were transmethylated by treatment with trimethylsulfonium hydroxide (Sigma). $10 \mu 1 \underline{\mu L}$ of fatty acid methyl esters (FAMEs) was injected into the capillary column (Phenomenex Zebron, ZB-FFAP, $30 \mathrm{~m}$ x $0.22 \mathrm{~mm}$ internal diameter) using a vaporising injector (split flow of $50 \mathrm{~mL} \_\mathrm{min}_{2}^{-\frac{1}{2}}$ ). The oven temperature was maintained at $120^{\circ} \mathrm{C}$ for $1 \mathrm{~min}$, and then increased to $250^{\circ} \mathrm{C}\left(5^{\circ} \mathrm{C} / \mathrm{min}^{-1} \mathrm{~min}\right)$ for 2 minutes. Hydrogen was used as a carrier gas at a flow rate of $0.5 \mathrm{Ml}-\underline{\mathrm{mL}} \mathrm{min}^{-1}$. Identification of fatty acids was made by comparing the relative retention times of FAME peaks of the samples with FAME standards. A standard library was also used through the "Thermo Scientific Xcalibur" software programme, to confirm identification by comparison of the mass spectrum.

\section{Determination of mineral content}

The mineral content was determined from microwave digested Arthrospira samples by ICP-MS (Thermo-Fisher Scientific-Icap-Q; Thermo Fisher Scientific, Bremen, Germany). The instrument was run employing collision-cell technology with kinetic energy discrimination (CCT-KED) to remove polyatomic interferences; the collision cell gas was He. Samples were introduced from an autosampler (Cetac ASX-520) incorporating an ASXpress $\frac{\text { TM }}{\text { rapid }}$ uptake module through a PEEK nebulizer (Burgener Mira Mist). Internal standards were introduced to the sample

\section{Formatted: Font: Not Italic}


stream on a separate line via the ASXpress unit and included Sc $\left(20 \mu \mathrm{g} \mathrm{L}^{-1}\right), \mathrm{Rh}\left(10 \mu \mathrm{g} \mathrm{L}^{-1}\right), \mathrm{Ge}\left(10 \mu \mathrm{g} \mathrm{L}^{-1}\right)$ and $\operatorname{Ir}(5$ $\mu \mathrm{g} \mathrm{L}^{-1}$ ) in $2 \%$ trace analysis grade (Fisher Scientific, UK) $\mathrm{HNO}_{3}$. External multi-element calibration standards (Claritas-PPT grade CLMS-2 from SPEX Certiprep Inc., Metuchen, NJ, USA) for $\mathrm{Cu}, \mathrm{Fe}, \mathrm{Mn}$, , Se and Zn were prepared in the range $0-100 \mu \mathrm{g} \mathrm{L}^{-1}\left(0,20,40,100 \mu \mathrm{g} \mathrm{L}^{-1}\right)$. A bespoke external multi-element calibration solution (PlasmaCAL, SCP Science, and France) was used to create $\mathrm{Ca}, \mathrm{Mg}$, Na and $\mathrm{K}$ standards in the range $0-30 \mathrm{mgL}^{-1}$. Phosphorus calibration utilized an in-house $\mathrm{KH}_{2} \mathrm{PO}_{4}$ solution standard $\left(10 \mathrm{mg} \mathrm{L}^{-1} \mathrm{P}\right)$.

Determination of phytonutrients

All phytonutrients were determined spectrophotometrically using Lamda 950 UV/VIS/NIR Spectrophotometer (Perkin Elmer, USA). Chlorophyll $a$ was determined according to AOAC (1995) after complete extraction (at least four times extraction) of the pigment from Arthrospira powder with $85 \%$ acetone. The absorbance of the extract was read at 666_nm and 642_nm against an 85\% acetone blank. Chlorophyll $a$ content of the samples was then calculated using the formula below.

Chlorophyll $a(\%)=[(9.93 \times$ Abs 666$)-(0.0777 \times$ Abs 642$)] \times 0.05$ liter $\times 100$

$$
\text { Sample weight (mg) X \%dry weight }
$$

The contents of phycobilproteins were estimated following the procedure developed by Yoshikawa and Belay (2008). These pigments were extracted from Arthrospira powder with 0.1M Na-Phosphate phosphate buffer (pH $6.0)$ and the content of each phycobiliprotein was measured at 618,620 and $650 \mathrm{~nm}$.

Total carotenoid content was estimated according to the method used by Cyanotech Corporation (2002) from the methanolic extract of the powder with subsequent extraction with diethyl ether. The maximum absorbance of the ether layer which contained the total carotenoids of the powder was measured at a wave length between $450 \mathrm{~nm}$ and $453 \mathrm{~nm}$ against a diethyl ether blank and the total carotenoids content was calculated using the following formula.

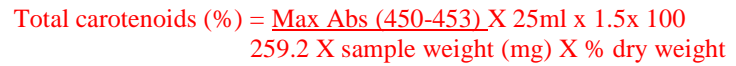

Where: $\mathrm{Max} \mathrm{Abs}=$ maximum absorbance

\section{Percent dry weight $=$ Weight of empty dish $(\mathrm{g})+$ dried powder $(\mathrm{g})$-Weight empty dish $(\mathrm{g})$ \\ Powder weight (not dried) (g)}

Beta-carotene was estimated from the methanolic extract of the powder with subsequent extraction with diethyl ether. The absorbance of the diethyl ether layer which contained the extracted $\beta$-carotene of the powder was measured at $436 \mathrm{~nm}$ against a diethyl ether blank and the $\beta$-carotene content was calculated using the following formula. 
$\beta$-carotene $(\%)=\underline{\operatorname{Abs} 436 \times 25 \mathrm{ml} \times 1.25 \times 100 \times 0.84}$

196 x sample wt (mg) X (\%) dry weight

Where: Abs =Absorbance

Percent dry weight=Weight of empty dish $(\mathrm{g})+$ dried powder $(\mathrm{g})$-Weight empty dish $(\mathrm{g})$

Powder weight (not dried) (g)

Statistical analysis

All data are expressed in terms of mean \pm standard deviation. The effects of seasonal variation on the proximate and phytonutrients composition of the dry biomass were analyzed by one-way ANOVA followed by post-hoc analysis with Tukey HSD test using the statistical program SPSS ver. 20. The effect of seasonal variation on the mineral composition of the biomass was analyzed using student's t-test. Significant levels for all analyses were set to $\mathrm{p}<$ 0.05 .

Results and discussion

Rainfall and temperature regime

Rainfall and temperature pattern of the lake area during the study period are shown in Fig $2 \mathrm{a}$ and $\mathrm{b}$ respectively. Based on the data, months from March to September were found to be wet (rainfall coefficient >0.6) and months from November to January were found to be dry (rainfall coefficients < 0.6). The rainfall pattern was similar with that reported by Wood and Talling (1988) and Klemperer and Cash (2007) for the general climate of Ethiopian rift valley lakes where wet season ranges from March to September and dry season ranges from October to February.

The maximum air temperature of the lake area varied from 24.0 to $28.9^{\circ} \mathrm{C}$ and from 26.7 to $29.4^{\circ} \mathrm{C}$ for wet and dry seasons respectively. The minimum air temperature varied from 11.6 to $16.8^{\circ} \mathrm{C}$ in the wet season and from 15.3 to $16.1^{\circ} \mathrm{C}$ in the dry season.

Physical and chemical characteristics of Lake Chitu

Some physical and chemical characteristics of Lake Chitu are presented in Table 1. The average $\mathrm{pH}$ value of the lake was $10.3 \pm 0.1$ and in both wet and dry seasons the $\mathrm{pH}$ was within the optimal $\mathrm{pH}$ range (9.5-10.5) that support the growth of many Arthrospira species (Vonshak 1997). High alkalinity and salinity values were recorded for the lake, which according to Wood and Talling (1988) is associated with the high evaporative concentration prevailing in the lake. Salinity values are usually expected to be lower in rainy seasons due to high precipitation and low evaporation. However, in this study high salinity values were recorded in wet months. Zinabu (2002) proposed the 
possible reason for these phenomena as exchange with sediments within the water bodies especially during frequent mixing which mostly occurs in rainy seasons.

Table 2 shows the inorganic mineral content of Lake Chitu as compared to the synthetic Zarrouk's medium (Zarrouk 1966). Sodium and potassium levels of Lake Chitu were very high compared to other minerals of the lake and levels found in the synthetic medium which can be attributed to their large concentration in the trachytic and rhyolitic rocks of the Ethiopian rift (Klemper and Cash 2007). The Ca and $\mathrm{Mg}$ contents of the lake were low and this can be explained by the high alkalinity of the lake which causes the removal of these ions from the solution as carbonate precipitates (Wood and Talling 1988). This phenomenon also occurs in some commercial production facilities where the raw water used to cultivate Arthrospira contains high content of calcium or magnesium (Belay 1997).

Biomass nutrient profile

Seasonal variation in the proximate composition of Arthrospira biomass harvested from Lake Chitu is presented in Table 3. The moisture content of the samples varied from 5.1 to $6.7 \%$ for wet season and from 5.8 to $6.1 \%$ for dry season samples with a mean value of $5.9 \pm 0.5 \%$. The moisture content of all biomass samples were within the recommended value of such types of products $(<7 \%)$ (Belay 2013) which is necessary to reduce water activity and inhibit microbial growth in the product.

The protein content of the biomass varied from 43.0 to $55.7 \%$ for wet and from 39.2 to $40.8 \%$ for dry season samples (Table 3). Wet season biomass samples had higher protein contents which may be related to nutrient availability in the lake during this season (Zinabu and Taylor 1989) as nutrients are released due to mixing caused by prevailing winds and possibly from runoff. The protein contents of wet season samples were within ranges (4571\%) reported for commercial Arthrospira (Belay 2008; Ortega et al. 1993; Fox 1996; Ortega et al. 1993Belay 2008). They are, however on the low side of values reported for most commercial products that are grown under more controlled conditions.

Changes in the carbohydrate content of the biomass were observed throughout the study period and varied from 30.9 to $36.4 \%$ for wet season and from 38.0 to $41.3 \%$ for dry season samples. Relatively higher carbohydrate contents were recorded in dry season biomass samples. Dry season is characterized by high salinity, high light intensity and nutrient deficiency (Kebede et al. 1994) which influence the synthesis of high amounts of carbohydrates (Zeng and Vonshak 1998; Olguin et al. 2001). Arthrospira is known to synthesize high amounts of trehalose at times of osmotic stress (Belay 2013).

In this study, the crude fat content of the biomass oscillated from 1.4 to $3.2 \%$ for wet season and from 1.9 to $2.5 \%$ for dry season samples. The fat content of the biomass was comparable to results obtained by others: $3.0 \%$ (Becker and Venkataraman 1984); 2-3 \% (De la Noiie and De Pauw 1988) and 2.5\% (Cafiizares-Villanueva et al. 1995). 
The crude fiber content of the biomass varied from 0.7 to $0.8 \%$ for wet season and from 0.6 to $0.9 \%$ for dry season biomass samples. These values were within the lower ranges reported for commercial Arthrospira (0.1_to_7.7\%) (Ortega et al. 1993; Fox 1996; Belay 2008Belay 2008; Fox 1996; Ortega et al. 1993).

The ash content of the biomass varied from 10.1 to $13.9 \%$ for wet season and from 16.1 to $18.7 \%$ for dry season biomass samples. All biomass samples had high ash contents compared to commercial Arthrospira (6.4 to $13 \%)$ (Ortega et al. 1993; Fox 1996; Belay 2008Belay 2008; Fox 1996; Ortege al. 1993) which might be due to the high amount of carbonate salts present in the lake. Additionally, it is possible that the washings with distilled water done before the samples were freeze dried may not have removed these salts completely. Washing with dilute acid may be necessary to reduce the ash content (Richmond 1998). High ash content may also result in high heavy metal content (unpublished data).

Amino acid composition

The amino acid profile of the biomass is presented in Table 4. Higher content of amino acids was recorded for a wet season biomass which could be associated with the difference in the protein and ash content of the samples. The essential amino acids isoleucine (Ile), leucine (Leu), methionine (Met), threonine (Thr), valine (Val), phenylalanine (Phe) and histidine (His) comprised $39.7 \%$ of the total amino acids for the wet season sample and $39.5 \%$ for the dry season sample. In both wet and dry season samples, leucine (Leu) was the highest essential amino acid. Misurcova et al. (2014) also reported the dominance of leucine among essential amino acids in their study on the amino acid composition of commercial algal products including Arthrospira.

The non-essential amino acid content (NEAs) of wet and dry season Arthrospira samples comprised $60.4 \%$ and $60.5 \%$ of the total amino acids respectively. In both samples, glutamic acid (Glu) was the highest amino acid taking a share of about $18 \%$ of the total amino acids followed by aspartic acid (Asp). The glutamic acid content of the biomass (especially the wet season sample) was higher compared to that reported for commercial Arthrospira (Richmond 1998; Belay 2008). The EA/NEA ratio of the biomass was $0.66 \%$ for the wet season and $0.65 \%$ for the dry season sample and these values were comparable with other Arthrospira strains: $0.50-0.65 \%$ (Ortega et al. 1993 ) and $0.60-0.70 \%$ (Fatma et al. 1994).

The amino acid composition of the biomass was compared with amino acid composition of artificially grown Arthrospira (Table 4). Arthrospira from Lake Chitu was inferior in the levels of most amino acids when compared to artificially grown Arthrospira. However, it is important to note that the quantities of sulphur containing amino acids (methionine and cysteine) were higher in Lake Chitu's Arthrospira compared to the artificially grown Arthrospira as well as values reported for commercial Arthrospira (Richmond 1998; Belay 2008). Ciferri (1983) indicated the existence of considerable variation in the amino acid profiles of Arthrospira from different sources especially in the concentration of the essential sulphur amino acids. There is currently a big interest by consumers 
for plant-based proteins. Due to problems of allergy associated with soy proteins, alternative proteins are being investigated, Arthrospira protein being one. However, Arthrospira is generally deficient in sulfur-containing amino acids compared to other conventional sources like soy protein and any improvement in the profile of these amino acids will be of great advantage.

Fatty acid composition

Five fatty acids corresponding to the most abundant fatty acids reported for various Arthrospira strains (Ortega et al. 1993; Campanella et al. 1999; Muhling et al. 2005) were identified including another medium-chain fatty acid (lauric acid) and expressed as weight percentage of total fatty acids (Table 5). Palmitic acid (16:0) was the dominant fatty acid in both wet and dry season samples followed by linoleic acid (18:2n6), $\gamma$ - linoleic acid (18:3n6) and oleic acid (18:1n9). While lauric acid (12:0) was the least abundant fatty acid for a wet season sample, it was found in relatively higher proportions in the dry season sample. The dominance of palmitic acid in the biomass is in line with results reported for artificially grown Arthrospira sp. (Cohen et al. 1987) which is due to the fact that the synthesis of fatty acids generally begins with saturated fatty acids in photosynthetic microorganisms (Morais et al. 2009). The gamma linoleic acid (GLA) content of the samples was found in higher quantities than that reported for some commercial Arthrospira (Campanella et al. 1999). GLA is a rare essential fatty acid which is found only in breast milk, the oil of primrose and Arthrospira and is reported to have several health benefits (Cohen et al. 1987; Dubacq and Pham-Quoc 1993).

Table 5 also shows the percentage contribution of saturated, monounsaturated and polyunsaturated fatty acids of the total fatty acids of the biomass. Relatively higher contents of saturated fatty acids were recorded for a dry season sample. Cohen et al. (1987) reported that the levels of saturated fatty acids increased in various Arthrospira strains when cultivation temperature increased. Although the biomass had low fat content, its fatty acid profile had some interesting characteristics. PUFAs (linoleic and GLA) contributed a high percentage of the total fatty acids in both wet and dry season samples. A higher content of polyunsaturated fatty acids (PUFA) increases the nutritional value of foods.

\section{Mineral composition}

The mineral content of the biomass is shown in Table 6. Significant differences were observed in the mineral contents of wet and dry season samples $(\mathrm{p}<0.05)$. Sodium was the most abundant mineral in both wet and dry season samples followed by potassium. The contents of these minerals were very high which might be due to the high concentration of these minerals in the lake. The mineral content of Arthrospira biomass from Lake Chitu is somewhat comparable to commercial Arthrospira with the exception of iron which is much lower in the lake's Arthrospira (28 mg $/ 100 \mathrm{~g}$ vs $70 \mathrm{mg} \_(100 \mathrm{~g} \text {-1-1)(Belay, unpublished data). Arthrospira is known to reduce iron- }$ deficiency anemia and has been studied for such in India and Africa. It is not known why iron content of the product is low even though the ash content of the biomass from the lake is significantly higher than that of commer cial Arthrospira. 
Phytonutrients composition

Figure 3 shows seasonal variation in the phytonutrients composition of the biomass. Chlorophyll $a$ contents of the biomass varied from 6.7 to $10.3 \mathrm{mg} \mathrm{g}^{-1}$ for wet season samples and from 6.5 to $7.13 \mathrm{mg} \mathrm{g}^{-1}$ for dry season samples. The presence of high concentration of chlorophyll $a$ in wet season biomass might be associated with light limitation due to clouds during this season (Zinabu 2002) as cyanobacteria produce higher amounts of chlorophyll $a$ to optimize the light harvesting process in lower light intensities (Ravelonandro et al. 2008; Danesi et al. 2012).

In this study, the total carotenoids content of the biomass varied from 1.97 to $4.31 \mathrm{mg} \mathrm{g}^{-1}$ for wet season and from 1.86 to $2.63 \mathrm{mg} \mathrm{g}^{-1}$ for dry season samples. Similarly, the $\beta$-carotene content of the biomass varied from 0.7 to $1.61 \mathrm{mg} \mathrm{g}^{-1}$ and from 0.88 to $1.0 \mathrm{mg} \mathrm{g}^{-1}$ during wet and dry season respectively. For both phytonutrients, higher values were recorded for wet season samples which may be due to synthesis of accessory pigments for light capture under the low light conditions of the wet and cloudy season (Kebede 1997). It could also be due to the higher availability of nutrients in the wet season.

The crude phycocyanin content of the biomass varied from 61.5 to $120.7 \mathrm{mg} \mathrm{g}^{-1}$ for wet and from 58.3 to $98.7 \mathrm{mg} \mathrm{g}^{-1}$ for dry season samples. Higher contents of these chromoproteins in wet season samples might be attributed to the low light conditions and high nutrient availability that prevail in the lake during this season. Seasonal and diurnal changes in phycocyanin content due to varying irradiation have been reported by Hidasi and Belay recently (in press).

\section{Conclusions}

The present study provided the first information on the seasonal profile of the nutritional composition of Arthrospira from a natural lake with the exception of that from a semi-natural Lake Texcoco in Mexico. The nutritional profile of Arthrospira biomass from the lake was found to be relatively comparable to commercially grown Arthrospira. The data presented provide baseline information for future studies on the sustainable exploitation of these natural resources. While direct harvest and utilization is not sustainable, it is possible to utilize the water and biomass from the lake to grow Arthrospira in ponds alongside the lake, with supplemental nutrients and recycling as is practiced in some commercial facilities in Inner Mongolia, China. Seasonal studies on biomass productivity and a thorough analysis of the safety of the product from this lake are essential in order to evaluate the economic feasibility of production of Arthrospira. The sustainable production and use of Arthrospira from this lake would no doubt have significant health and economic benefit to the local community and beyond. 
References

AOAC (1995) Official Methods of Analysis. 940.03. Chlorophyll in plants. Association of Official Analytical Chemists, Washington, DC

AOAC (2000) Association of Official Analytical Chemists official method analysis__ (AOAC International. Washington DC, USA

American Public Health Association (APHA), American Water Works Association (AWWA), Water Environment Federation (WEF) (1999) Standard methods for the examination of water and waste water. $20^{\text {th }}$ ed. Washington, DC

Aissaoui O, Amiali M, Bouzid N, Belkacemi K, Bitam A (2017) Effect of Spirulina platensis ingestion on the abnormal biochemical and oxidative stress parameters in the pancreas and liver of alloxan-induced diabetic rats. Pharm Biol. 55(1):1304-1312

Becker EW, Venkataraman LV (1984) Production and utilization of the blue-green Alga-alga Spirulina in India. Biomass 4: 105-125

Becker EW (2007) Micro-algae as a source of protein. Biotechnology Advances 25: 207-210

Belay A (2002) The potential application of Spirulina (Arthrospira) as a nutritional and therapeutic supplement in health management. Jeurnal of Ameriean Nutraceutieal Association 5(2): 27-48

Belay A (2013) Biology and industrial production of Arthrospira (Spirulina). In: Richmond A, Hu Q (eds) Handbook of Microalgal Culture Applied Phycology and Biotechnology. $2^{\text {nd }}$ ed. John Wiley \& Sons, Ltd, Oxford, UK, pp 339-358

Belay A (1997) Mass culture of Spirulina outdoors. The Earthrise Farms experience. In: Vonshak A(ed) Spirulina platensis (Arthrospira): physiology, cell-biology and biotechnology. Taylor \& Francis, London, pp 131-158

Belay A (2008) Spirulina (Arthrospira): Production and Quality Assurance. In: Gershwin ME, Belay A (eds) Spirulina in human nutrition and health. CRC press, Boca Raton, pp 1-25 
Bermejo-Bescós P, Piñero-Estrada E, Villar del Fresno A M (2008) Neuroprotection by Spirulina platensis protean extract and phycocyanin against iron-induced toxicity in SH-SY5Y neuroblastoma cells.Toxicol_Ænn Vitro 22(6):1496-1502

Cafiizares-Villanueva RO, Dolrdnguez AR, Cruz MS, Ros-Leal E (1995) Chemical composition of cyanobacteria grown in diluted, aerated swine wastewater. Bioresource Technolegy 51:111-116

Campanella L, Crescentini G, Avino P (1999) Chemical composition and nutritional evaluation of some natural and commercial food products based on Spirulina. Analusis 27:533-540

Formatted: Font: Italic

Cohen Z, Vonshak A, Richmond A (1987) Fatty acid composition of Spirulina strains grown under various environmental conditions. Phytochemistry 26:2255-2258

Cohen Z (1997) The chemicals of Spirulina. In: Vonshak A (ed) Spirulina platensis (Arthrospira): physiology, cellbiology and biotechnology. Taylor \& Francis, London, pp 175-204

Cyanotech Corporation (2002) Analysis of $\beta$-carotene and total carotenoids from Spirulina (Spectrophotometric method). Spirulina Pacifica technical bulletin. http://www. Cyanotech.com/pdfs/spirulina/spbul3.pdf

Danesi EDG, Rangel-Yagui CO, Sato S, de Carvalho JCM (2012) Growth and content of Spirulina platensis biomass chlorophyll cultivated at different values of light intensity and temperature using different nitrogen sources. Brazilian Jeurnal of Microbiolegy 42: 362-373

De la Noiie J, De Pauw N (1988) The potential of microalgal biotechnology: a review of production and uses of microalgae. Biotechnolegical Advances 6: 725-770

Dubacq JP, Pham-Quoc K (1993) Biotechnology of Spirulina lipids: a source of gamma-linolenic acid. In: Doumenge F, Durand- Chastel H, Toulemont A (eds) Spirulina Algae of life. Musee Oceanographique, Monaco, pp $59-64$

Fatma T, Sarada R, Venkataraman, LV (1994) Evaluation of selected strains of Spirulina for their constituents. Phykos 33:89- 97 
Golterman HL, Clymo RS, Ohnstad MAM (1978) Methods for physical and chemical analysis of freshwaters. IBP Handbook No. 8, Blackwell Scientific Publications

Guan XY, Zhang WJ, Zhang XW, Li YX, Wang JF, Lin H Z, Tang XX, Qin S (2009) A potent anti-oxidant property: fluorescent recombinant alphaphycocyanin of Spirulina. J Appl Microbiol 106(4):1093-2000

Hayashi T, Hayashi K, Maedaa M, Kojima I (1996) Calcium spirulan, an inhibitor of enveloped virus replication, from a blue green alga Spirulina platensis. J Nat Prod_-59:83-87

James CS (1996) Analytical Chemistry of Foods. Chapman and Hall, New York

Johnson PE, Shubert LE (1986) Accumulation of mercury and other elements by Spirulina (Cyanophyceae). NutrRep- Int: 34: 1063-1070

Kebede E (1997) Response of Spirulina platensis (Artherospira fusiforms) from Lake Chitu, Ethiopia, to salinity stress from sodium salts. Jeurnal of Applied_Phycolegy 9: 555 - 558

Kebede E, Ahlgren G (1996) Optimum growth conditions and light utilization efficiency of Spirulina platensis (=Arthrospira fusiformis) (Cyanophyta) from Lake Chitu, Ethiopia. Hydrobiologia 332(2): 99-109

Kebede E, GebreMariam Z, Ahlgren I (1994) The Ethiopian Rift Valley lakes: chemical characteristics of a salinityalkalinity series. Hydrobiologia 288: 1-12

Mendiola JA, Marin FR, Hernandez SF, Arredondo BO, Senorans FJ, Ibanez E, Reglero G (2005) Characterization via liquid chromatography coupled to diode array detector and tandem mass spectrometry of supercritical fluid antioxidant extracts of Spirulina platensis microalga. J. Separa- Sci- 28: 1031-1038

Formatted: Font: Italic

Mishima T, Murata J, Toyoshima M, Fujii K, Nakajima M, Hayashi T, Kato T, Saiki I(1998) Inhibition of tumor invasion and metastasis by calcium spirulan (Ca-SP), a novel sulfated polysaccharide derived from a blue-green alga, Spirulina platensis. Clin Exp Metastasis- 16:541-550 
Okuyama H, Tominaga A, Fukuoka S, Taguchi T, Kusumoto Y, Ono S (2017) Spirulina lipopolysaccharides inhibit tumor growth in a Toll-like receptor 4-dependent manner by altering the cytokine milieu from interleukin17/interleukin-23 to interferon- $\gamma$. Oncol Rep 37(2):684-694

Olguin E, Galicia S, Angulo-Guerrero O, Hernndez E (2001) The effect of low light flux and nitrogen deficiency on the chemical composition of Spirulina sp. (Arthrospira) grown on digested pig waste. Bioresouce-Bioresour Technolegy 77: 19-24

Ortega JJ, Mazuelos C, Hermosin B, Saiz C (1993) Chemical composition of Spirulina and eukaryotic algae food products marketed in Spain. Jeurnal-of Applied Phycolegy 4: 425-35

Ravelonandro PH, Ratianarivo DH, Joannis-Cassan C, Isambert A, Raherimandimby M (2008) Influence of light quality and intensity in the cultivation of Spirulina platensis from Toliara (Madagascar) in a closed system. Jemmat ef Chemical Technolegy and Biotechnolegy 83(6):842-848

Richmond A (1998) Spirulina. In: Borowitzka MA, Borowitzka LJ (eds) Micro_algal Biotechnology, Cambridge University Press, Cambridge, pp 85-121

Riss J, Décordé K, Sutra T, Delage M, Baccou JC, Jouy N, Brune JP, Oréal H, Cristol J P, Rouanet JM (2007) Phycobiliprotein C-phycocyanin from Spirulina platensis is powerfully responsible for reducing oxidative stress and NADPHoxidase expression induced by an atherogenic diet in hamsters. J Agric Food Chem. 55(19):7962-7967

Shih CM, Cheng SN, Wong CS, Kuo YL, Chou TC (2009) Antiinflammatory and antihyperalgesic activity of Cphycocyanin. AnesthAnalg 108(4):1303-1310

Stahl W, Sies H (2005) Bioactivity and protective effects of natural carotenoids. BiochimicaetBiophysicaActa Biochim Biophys Acta (BBA)-Molecular Basis ef-Disease 1740(2): 101-107

Subhashini J, Mahipal SV, Reddy MC, Mallikarjuna RM, Rachamallu A, Reddanna P (2004) Molecular mechanisms in C-Phycocyanin-phycocyanin induced apoptosis in human chronic myeloid leukemia cell line-K562. Biochem Pharmacol 68(3):453-462

Vonshak A (ed) (1997) Spirulina platensis (Arthrospira): physiology, cell-biology and biotechnology. Taylor \& Francis, London

Vonshak A, Richmond A (1988) Mass production of the blue-green alga Spirulina: An Өverviewoverview. Biomass 15: $233-247$ 
Willen E, Ahlgren G, Tilahun G, Spoof L, Neffling MR, Meriluoto J (2011) Cyanotoxin production in seven Ethiopian Rift Valley lakes. Inland Waters 1: 81-91

Wood RB, Talling JF (1988) Chemical and algal relationships in salinity series of Ethiopian inland waters. Hydrobiologia 158: 29-67

Yoshikawa N, Belay A (2008) Single laboratory validation of a method for the determination of c--phycocyanin and allophycocyanin in Spirulina (Arthrospira) supplements and raw materials by spectrophotometry. Jeurnal of AOAC International $91(3): 524-529$

Zarrouk C (1966) Contribution l'étude d'une cyanophycée. Influence de divers facteurs physiques et chimiques sur la croissance et la photosynthése de Spirulina maxima. Doctoral thesis, University of Paris, Zarrouk C (1966) Contribution a !'etude d'une cyanophyt 'l'1' Influence de divers facteurs physiques et chimiques su1 1 , 1 croissance ed Ia photosynthese de Spirulina maxima (Seidl ct Gardner) Gietler. These de Doctoral, Paris

Zeng MT, Vonshak A (1998) Adaptation of Spirulina platensis to salinity-stress. Comparative Biochemistry and Physiolegy Part A : Molecular \& Integrative Physiology-120(1): 113-118

Zinabu GM, Taylor WD (1989) Seasonal and spatial variation in abundance, biomass and activity of heterotrophic bacterioplankton in relation to some biotic and abiotic variables in an Ethiopian rift-valley lake (Awassa). Freshwater Biology 22: 355-368

Zinabu GM (2002) The effects of wet and dry seasons on concentrations of solutes and phytoplankton biomass in seven Ethiopian rift-valley lakes. Limnologica 32: 169-179 


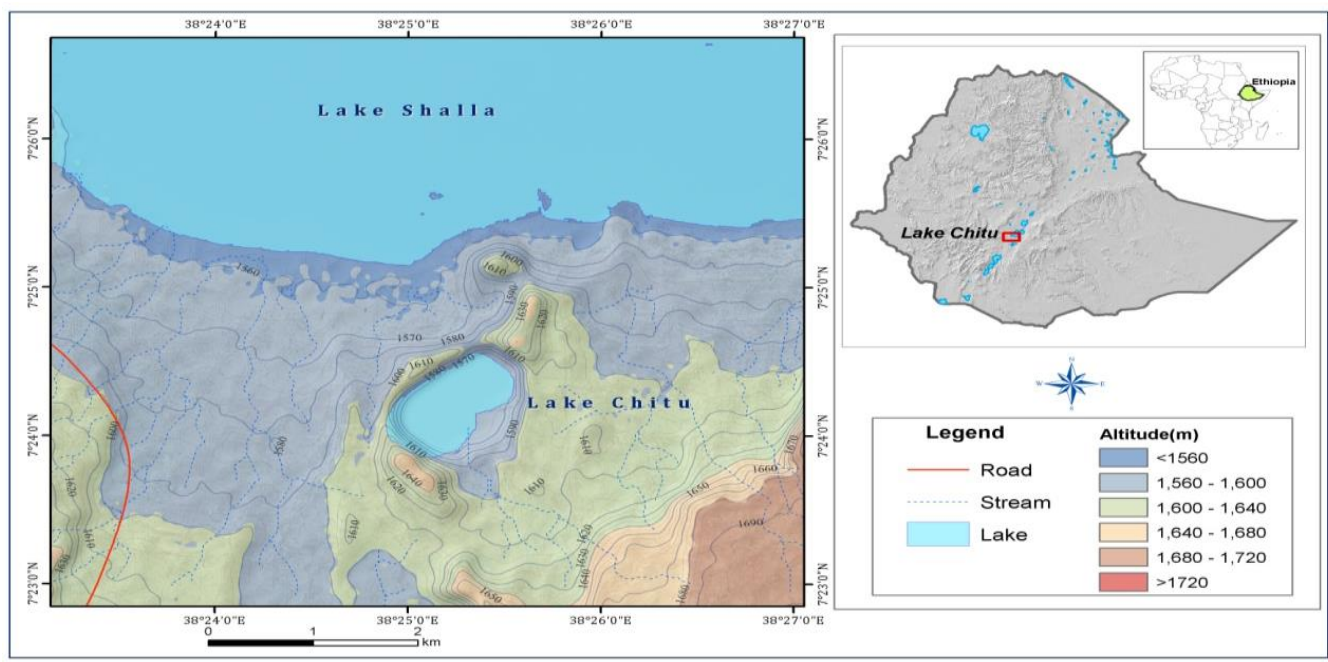

Fig 1. Location of the study site (Lake Chitu)

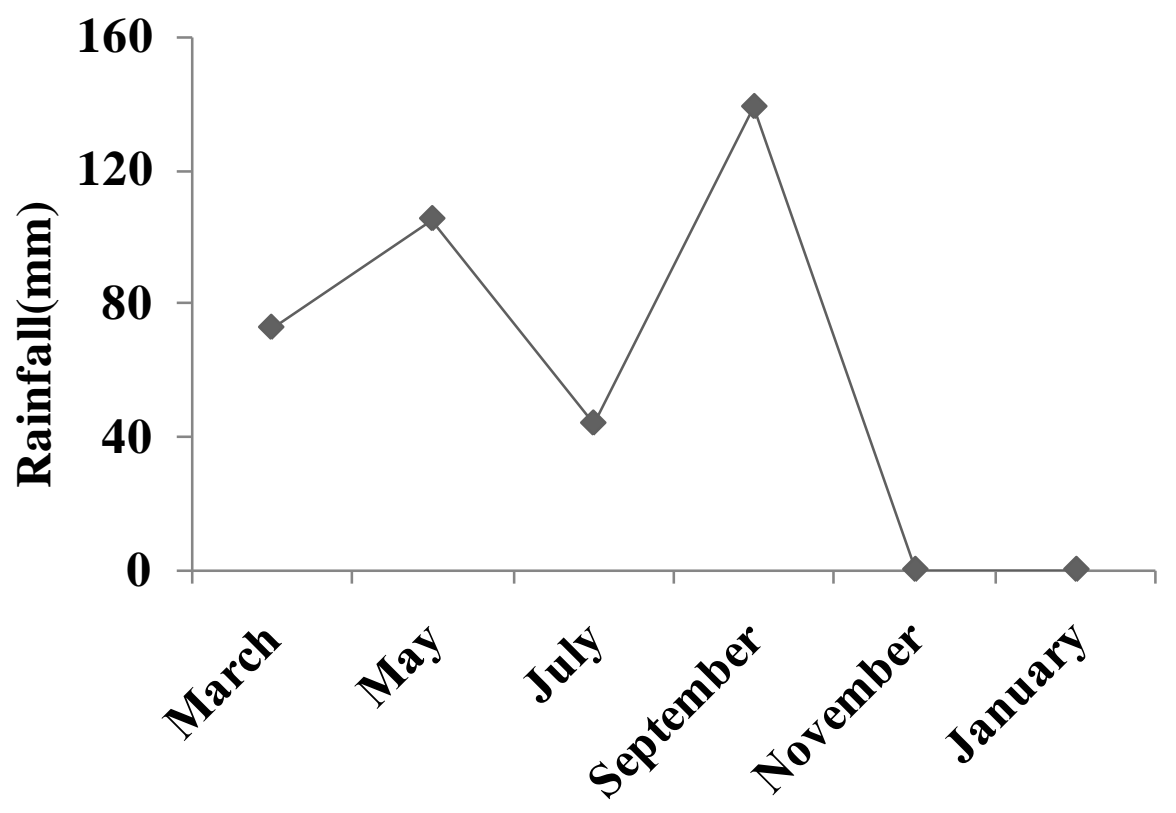

a) 


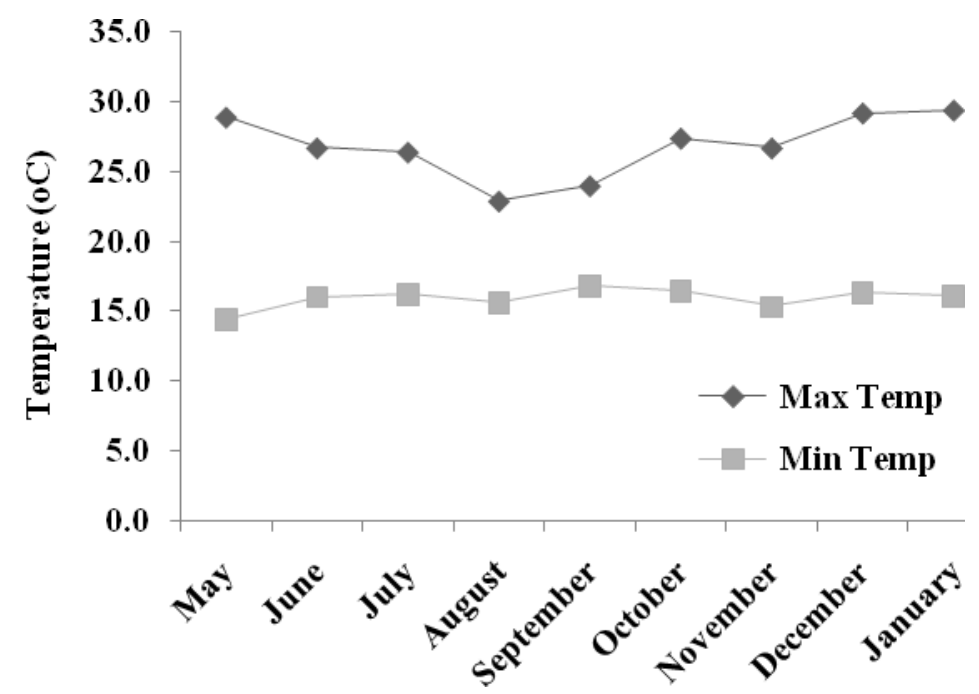

b)

Fig 2. Rainfall (a) and Temperature (b) pattern of Lake Chitu area during the sampling period (March 2012January 2013)

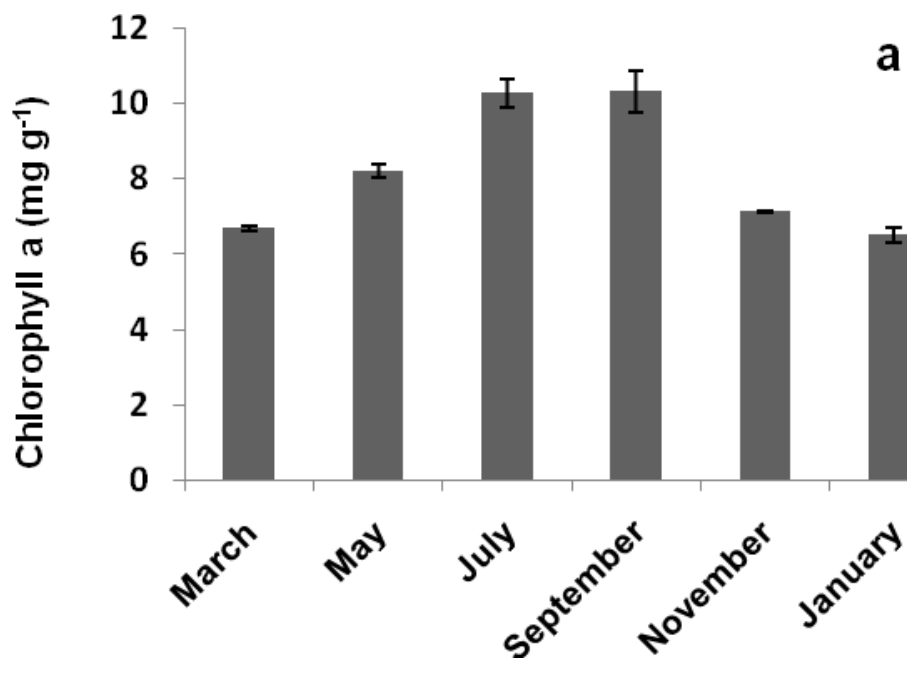



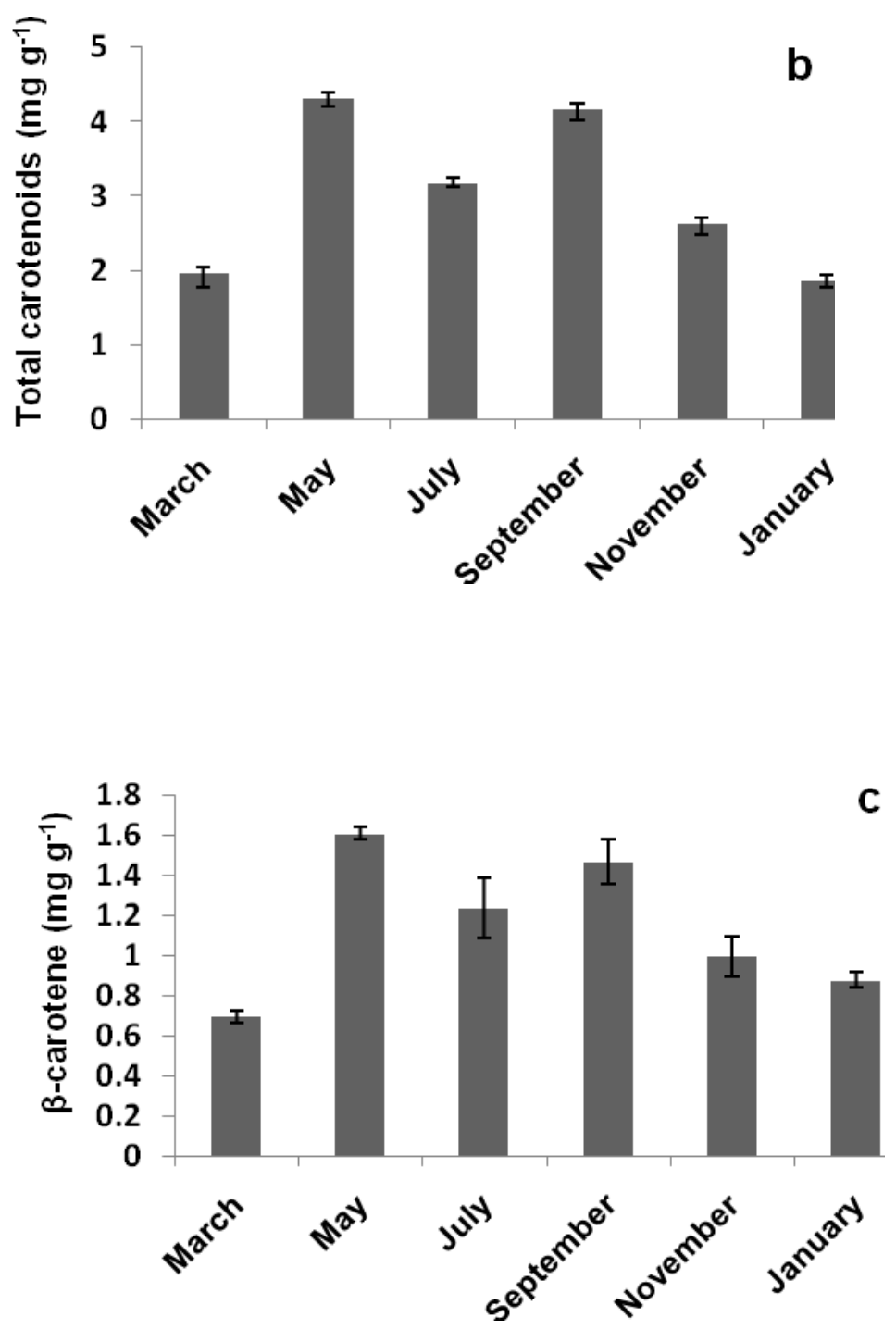


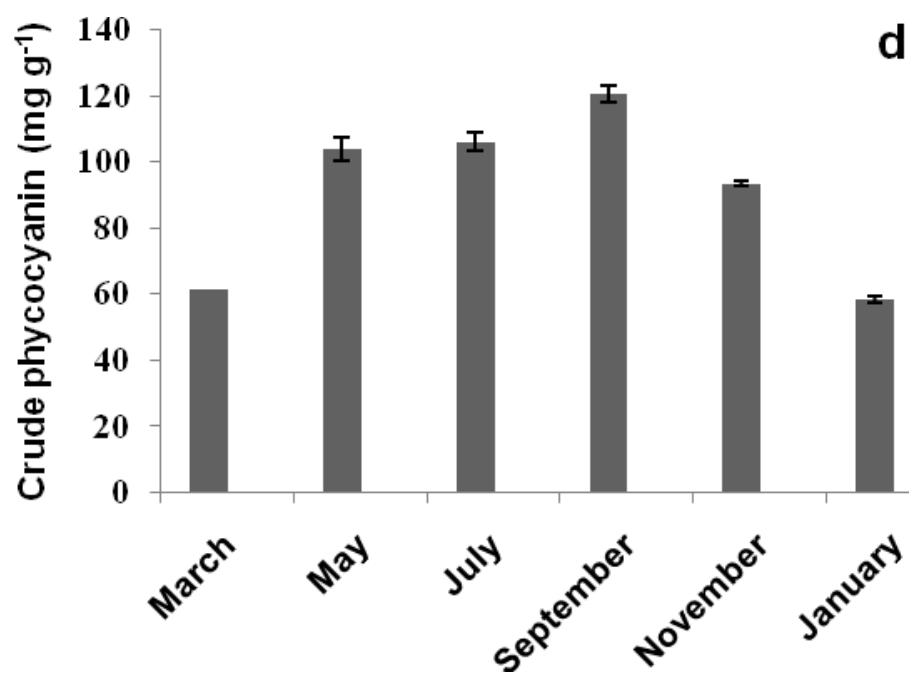

Fig 3. Seasonal variation in the phytonutrients composition of Lake Chitu's Arthrospira (Mean \pm SD; $n=3$ ). Chlorophyll $a$ (a) Total carotenoids (b) $\beta$-carotene (c) and Crude phycocyanin (d). Error bars represent the standard deviation of means, $n=3$ ) 
Table 1. Physical and chemical characteristics of Lake Chitu during the study period (March 2012-January 2013)

\begin{tabular}{llll}
\hline Physicochemical parameters & Mean \pm SD & \multicolumn{2}{c}{ Range } \\
\cline { 3 - 4 } & $(\mathrm{n}=6)$ & Wet season & Dry season \\
$\mathrm{pH}$ & $10.3 \pm 0.1$ & $10.3-10.4$ & $10.2-10.3$ \\
Salinity $\left(\mathrm{gL}^{-1}\right)$ & $55 \pm 3.34$ & $53-60.1$ & $51-55$ \\
Alkalinity $\left(\mathrm{meqL}^{-1}\right)$ & $681.4 \pm 44.5$ & $637-740$ & $680-710$ \\
\hline
\end{tabular}

Table 2. Inorganic mineral contents of Lake Chitu as compared to Zarrouk's medium

\begin{tabular}{llll}
\hline Inorganic minerals & \multicolumn{2}{c}{ Lake Chitu } & \\
\cline { 2 - 3 }$\left(\mathrm{mLL}^{-1}\right)$ & 18065 & 18689 & 3800 \\
$\mathrm{na}$ & 1981 & 1200 & 125 \\
$\mathrm{~K}$ & 0.22 & 0.18 & 0.4 \\
$\mathrm{Fe}$ & 0.034 & 0.022 & \\
$\mathrm{Cu}$ & 0.01 & 0.01 & 13.3 \\
$\mathrm{Zn}$ & n.d season & n.d & 7.0 \\
$\mathrm{Ca}$ & 1.00 & 0.18 & \\
$\mathrm{Mg}$ & & & \\
\hline * Zarrouk 1966 & & & \\
n.d: not detected & &
\end{tabular}


Table 3. Seasonal variation in proximate composition (\%, dry matter) and energy value (Kcal) Arthrospira biomass harvested from Lake Chitu (mean $\pm S D, n=3$ )

Lake Chitu's Arthrospira

\begin{tabular}{|c|c|c|c|c|c|c|}
\hline & \multirow[b]{2}{*}{ March } & \multicolumn{3}{|c|}{ Wet season harvest } & \multicolumn{2}{|c|}{ Dry season harvest } \\
\hline & & May & July & September & November & January \\
\hline Moisture & $6.7 \pm 0.07^{\mathrm{d}}$ & $6.4 \pm 0.34^{\mathrm{a}}$ & $6.2 \pm 0.09^{\mathrm{a}}$ & $5.1 \pm 0.05^{\mathrm{c}}$ & $6.1 \pm 0.06^{\mathrm{ab}}$ & $5.8 \pm 0.12^{\mathrm{b}}$ \\
\hline Protein & $43.0 \pm 0.8^{\mathrm{d}}$ & $55.7 \pm 0.58^{\mathrm{a}}$ & $48.2 \pm 0.2^{b}$ & $47.9 \pm 0.11^{\mathrm{b}}$ & $39.2 \pm 0.36^{\mathrm{c}}$ & $40.8 \pm 1.62^{\mathrm{c}}$ \\
\hline $\mathrm{CHO}$ & $34.8 \mathrm{~b} \pm 1.4^{\mathrm{b}}$ & $30.9 \pm 0.5^{\mathrm{a}}$ & $36.4 \pm 0.54^{\text {bd }}$ & $34.5 \pm 0.1^{\mathrm{b}}$ & $41.3 \pm 0.44^{\mathrm{c}}$ & $38.0 \pm 1.69^{\mathrm{d}}$ \\
\hline Fat & $1.4 \pm 0.3^{\mathrm{d}}$ & $2.5 \pm 0.11^{\mathrm{a}}$ & $2.6 \pm 0.19^{\mathrm{ab}}$ & $3.20 \pm 0.07^{\mathrm{c}}$ & $2.5 \pm 0.18^{b}$ & $1.9 \pm 0.06^{\mathrm{d}}$ \\
\hline Fiber & $0.70 \pm 0.1^{\mathrm{a}}$ & $0.7 \pm 0.04^{\mathrm{a}}$ & $0.8 \pm 0.08^{\mathrm{ab}}$ & $0.6 \pm 0.09^{\mathrm{a}}$ & $0.9 \pm 0.15^{\mathrm{b}}$ & $0.6 \pm 0.1^{\mathrm{a}}$ \\
\hline Ash & $13.1 \pm 0.08^{c}$ & $10.1 \pm 0.1^{\mathrm{a}}$ & $12.0 \pm 0.61^{\mathrm{b}}$ & $14.0 \pm 0.15^{\mathrm{c}}$ & $16.1 \pm 0.06^{\mathrm{d}}$ & $18.7 \pm 0.05^{\mathrm{e}}$ \\
\hline Energy & $323.8 \pm 2.6^{\mathrm{a}}$ & $369.1 \pm 0.6^{\mathrm{b}}$ & $361.8 \pm 1.66^{\mathrm{c}}$ & $358.1 \pm 0.64^{\mathrm{d}}$ & $344.6 \pm 1.28^{\mathrm{e}}$ & $332.4 \pm 0.76^{\mathrm{f}}$ \\
\hline
\end{tabular}

In each raw different letters indicate significant differences $(\mathrm{p}<0.05)$ 
Table 4. Amino acid composition of Arthrospira biomass (g/100g protein) harvested from Lake Chitu

\begin{tabular}{|c|c|c|c|}
\hline Amino acids & $\begin{array}{l}\text { Wet season } \\
\text { harvest }\end{array}$ & $\begin{array}{l}\text { Dry season } \\
\text { harvest }\end{array}$ & $\begin{array}{l}\text { *Arthrospira } \\
\text { (Artificially } \\
\text { grown) }\end{array}$ \\
\hline \multicolumn{4}{|l|}{ Essential amino acids(EA) } \\
\hline Ile & 3.21 & 2.38 & 6.7 \\
\hline Leu & 6.18 & 4.65 & 9.8 \\
\hline Lys & 5.23 & 4.35 & 4.8 \\
\hline Met & 2.85 & 2.10 & 2.5 \\
\hline Phe & 3.66 & 2.70 & 5.3 \\
\hline Thr & 4.27 & 3.24 & 6.2 \\
\hline Val & 4.21 & 3.16 & 7.1 \\
\hline His & 2.50 & 1.90 & 2.2 \\
\hline \multicolumn{4}{|l|}{ Non essential amino acids(NEAs) } \\
\hline Cys & 6.17 & 4.97 & 0.9 \\
\hline Tyr & 2.72 & 2.11 & 5.3 \\
\hline Asp & 6.92 & 5.20 & 10.3 \\
\hline Glu & 15.30 & 11.80 & 11.8 \\
\hline Ser & 4.46 & 3.35 & 5.1 \\
\hline Gly & 4.22 & 3.17 & 5.7 \\
\hline Ala & 4.01 & 3.13 & 9.5 \\
\hline Arg & 5.08 & 3.85 & 7.3 \\
\hline Amm & 5.44 & 4.06 & \\
\hline Total amino acids & 86.43 & 66.12 & \\
\hline Essential amino acids( EA) & 39.7 & 39.5 & \\
\hline Non essential amino acids( NEA) & 60.4 & 60.5 & \\
\hline EA/NEA & 0.66 & 0.65 & \\
\hline
\end{tabular}

* Richmond 1998 
Table 5. Fatty acid composition of Arthrospira biomass harvested from Lake Chitu during wet and dry seasons $(\mathrm{g} / 100 \mathrm{~g}$ dry weight $)($ mean $\pm \mathrm{SD}, \mathrm{n}=3)$

\begin{tabular}{lll}
\hline Fatty acid (\%) & Lake Chitu's Arthrospira \\
\hline & Wet season harvest & Dry season harvest \\
\cline { 2 - 3 } Palmitic (16:0) & $31.7 \pm 2.88^{\mathrm{a}}$ & $29.2 \pm 1.65^{\mathrm{a}}$ \\
Linoleic (18:2n6) & $23.7 \pm 2.61^{\mathrm{a}}$ & $25.6 \pm 4.45^{\mathrm{a}}$ \\
C-linolenic (18:3n6) & $20.3 \pm 5.19^{\mathrm{a}}$ & $16.0 \pm 0.51^{\mathrm{a}}$ \\
Oleic (18:1n9) & $11.9 \pm 0.35^{\mathrm{a}}$ & $10.3 \pm 4.06^{\mathrm{a}}$ \\
Palmitoleic (16:1n9) & $5.9 \pm 0.87^{\mathrm{a}}$ & $6.3 \pm 0.15^{\mathrm{a}}$ \\
Lauric (12:0) & $4.8 \pm 3.56^{\mathrm{a}}$ & $12.7 \pm 1.33^{\mathrm{b}}$ \\
Saturated (SFA) & 37.1 & 41.9 \\
Monounsaturated (MUFA) & 18.1 & 16.6 \\
Polyunsaturated (PUFA) & 44.8 & 41.6 \\
PUFA/SFA & 1.21 & 0.99 \\
\hline
\end{tabular}

In each raw different letters indicate significant differences $(p<0.05)$

Table 6. Major and trace minerals content (mg/100g dry matter) of Arthrospira biomass harvested from Lake Chitu $($ mean $\pm \mathrm{SD}, \mathrm{n}=3)$

\begin{tabular}{lcc}
\hline Minerals & \multicolumn{2}{c}{ Lake Chitu's Arthrospira } \\
\cline { 2 - 3 } & Wet season harvest & Dry season harvest \\
\cline { 2 - 3 } Major & $3387 \pm 330^{\mathrm{a}}$ & $5986 \pm 507^{\mathrm{b}}$ \\
$\mathrm{Na}$ & $1564 \pm 234^{\mathrm{a}}$ & $2044 \pm 197^{\mathrm{b}}$ \\
$\mathrm{K}$ & $639 \pm 121^{\mathrm{a}}$ & $514.5 \pm 64^{\mathrm{b}}$ \\
$\mathrm{P}$ & $55.0 \pm 7^{\mathrm{a}}$ & $45.7 \pm 15^{\mathrm{b}}$ \\
$\mathrm{Ca}$ & $112.1 \pm 18^{\mathrm{a}}$ & $76.6 \pm 7^{\mathrm{b}}$ \\
$\mathrm{Mg}$ & & \\
& & \\
Trace & & \\
\hline
\end{tabular}




\begin{tabular}{lll}
\hline $\mathrm{Mn}$ & $1.81 \pm 0.31^{\mathrm{a}}$ & $1.30 \pm 0.03^{\mathrm{b}}$ \\
$\mathrm{Fe}$ & $27.9 \pm 5.61^{\mathrm{a}}$ & $18.5 \pm 1.91^{\mathrm{b}}$ \\
$\mathrm{Cu}$ & $0.06 \pm 0.04^{\mathrm{a}}$ & $0.04 \pm 0.05^{\mathrm{b}}$ \\
$\mathrm{Zn}$ & $0.05 \pm 0.21^{\mathrm{a}}$ & $0.04 \pm 0.29^{\mathrm{b}}$ \\
$\mathrm{Se}$ & $0.03 \pm 0.01^{\mathrm{a}}$ & $0.01 \pm 0.01^{\mathrm{b}}$ \\
\hline
\end{tabular}

In each raw different letters indicate significant differences $(\mathrm{p}<0.05)$ 